\title{
Maids at the grindstone: A comparative study of New Kingdom Egypt grain grinders
}

\author{
Elizabeth Lang \\ Yale University, Department of Near Eastern Languages and Civilizations, New Haven, CT, U.S.A. \\ Email: elizabeth.lang@yale.edu
}

\begin{abstract}
:
Grinding (or milling) grain was an important activity that took place in nearly every ancient Egyptian home. Grinding was necessary to process emmer or barley grain into flour, and thus was a key step in manufacturing bread, the most important food in ancient Egypt. Grinding in ancient Egypt is well-attested archaeologically, and is the most commonly depicted activity of the grain processing sequence in Egyptian art and texts. Indeed, it was the step that likely took the most time and labour. Despite their significance to daily life in ancient Egypt, grinding implements and activities have often been ignored in archaeological reports and historical studies. However, recent investigations of contemporary ancient cultures as well as modern ethnographic work has brought grind stones and grinding to the fore. This has resulted in new archaeological and ethnographic information, and has refined theories regarding grain grinding and those who performed it. Using this cross-cultural body of evidence and theoretical discussion as a starting point, this presentation will investigate grinding in the domestic, non-elite sphere of New Kingdom Egypt. Using the grinding quern as a focus, this study will explore how association with a grind stone, as well as the act of grinding, created or impacted the miller's identity and contributed to their role in the household. Archaeological data, 2D and 3D artistic representations of grinding, and literary and non-literary texts discussing grinding will be examined in conversation with evidence from other cultures. This paper will argue that grinding grain was particularly associated with females, and was a low-prestige activity. However, it was an important maintenance activity in the household, and contributed significantly to the labour force and economy of New Kingdom Egypt.
\end{abstract}

Keywords: milling; Egypt; household; women; identity; ground stone tools

\section{Introduction}

Bread in ancient Egypt was the primary food eaten every day, and the main source of calories. Estimates for the percentages of calories provided by bread for people in the Eastern Mediterranean each day range between 50-75\%, (Foxhall \& Forbes 1982; Meyers 2002) and was probably similar in ancient Egypt. Bread was a nutritious staple food that was also economically important: as a dry, self-contained food, it was highly portable. Bread could be baked ahead of time and taken out of the house, allowing the labour of a household unit to be dispersed much further afield. Bread was also ritually very important in ancient Egypt: nearly

Published by the School of History, Classics and Archaeology, University of Edinburgh ISSN: 2055-0472. URL: http://journals.ed.ac.uk/lithicstudies/

This work is licensed under a Creative Commons Attribution 2.5 UK: Scotland License. 
without fail, it is the first and sometimes only foodstuff listed as an offering to the dead, and an important aspect of offerings given to the gods.

Despite bread's significance to ancient Egyptian life, being crucial to cuisine, economy, and religion, it has often been ignored in modern scholarship. In particular, those who made the bread, especially at the non-elite level, have been neglected, with the few studies which investigate bread-baking focusing on the physical processes the grains undergo, rather than the individuals who performed these processes. This paper will investigate the individuals who created this crucial food in the non-elite household, concentrating on their performance of one step in the process, that of grinding grain into flour (milling). Using the grinding stone (quern) as a focus, this study will explore the grinding process, and how association with a grinding stone, as well as the act of grinding itself, created or impacted the miller's identity and contributed to her role in the non-elite household. Drawing on archaeological, textual, and artistic sources, as well as a wide variety of comparative information, this paper will argue that grinding grain was particularly associated with females, and was a low-prestige activity. However, it was also an important maintenance activity in the household, and contributed significantly to the labour force and economy of New Kingdom Egypt.

\section{Materials:}

This study will focus on the experience of household millers in two New Kingdom towns: the late 18th dynasty (c. 1350-1330 BCE) Walled Village near Amarna, and Deir elMedina, across the river from Thebes, occupied from the early 18th to 20th dynasties (c. 1500-1080 BCE). Both villages were founded by the state, and housed government-employed workers. At Deir el-Medina these workers excavated and decorated the royal tombs of the Valleys of the Kings and Queens, and it is possible workers in Amarna also laboured to construct the elite tombs in the wadi east of the main city. Unlike many non-elites in Egypt, the inhabitants of these two villages did not farm as their main source of income; rather they were supplied with rations by the government in return for their tomb-building work. The Amarna Walled Village was inhabited for less than 20 years and never occupied again, while Deir el-Medina was inhabited for several centuries, though never subsequently re-occupied after being abandoned. Thus both sites were excellently preserved until excavations began in the early twentieth century. The Amarna Walled Village was excavated primarily in the 1920s-1930s (Woolley 1922; Peet \& Woolley 1923) and from the 1970s on (Kemp 1984; 1986; 1987). The village of Deir el-Medina was excavated mainly in the early twentieth century (Schiaparelli 1923; Bruyère 1939).

The Amarna Walled Village and Deir el-Medina supply good evidence for analysing bread production activities for several reasons. The houses at these sites were excellently preserved; in particular, the bread-preparing equipment at Amarna survived more or less intact in several cases (Peet 1921; Woolley 1922; Peet \& Woolley 1923; Kemp 1987: 40-44). Though little written material from Amarna has survived, and none concerned with grain supply or bread production, an enormous amount of written material was found at Deir elMedina which provides useful evidence regarding the role of women grinding grain in the household. In addition, comparative evidence from earlier periods in Egypt is preserved in the form of artistic evidence from tombs and texts.

\section{Results:}

Grain grinding was one of the final steps in the emmer processing sequence (Samuel 1994: 157-162; 1999; 2000; 2010: 463-464). In New Kingdom Egypt, emmer was stored in granaries while still in the spikelet (the inedible chaff and glume which tightly encased the edible emmer seed). Storing grain like this protected it from insect attack, but meant that on a 
daily basis in the household, the glume and chaff had to be removed before the clean seed could be ground into flour. This was done by pounding the emmer in a mortar with a small amount of water. It has been suggested that parching was required to facilitate this process, but experimental archaeology has shown that this was unnecessary (Samuel 1994: 151), and no textual or artistic evidence attests to parching, so it has been left out of the emmer processing sequence here. After the pounded material had dried, it could be sieved to separate the clean grain from the chaff and glume material, after which the milling process could take place (see below).

Once all the grain had been ground into flour, it was mixed with water and sometimes other ingredients. It is uncertain whether or not Egyptian bread was leavened, but little evidence has surfaced suggesting it was (Samuel 1994: 280-283), so this article will operate on the assumption that leavening was not necessary. Following the mixing, dough was kneaded. If it was not leavened, it may not have needed a resting period, as it would not rise significantly. Dough could immediately be formed into loaves, likely flat and circular in shape, and placed inside the oven to bake. Ovens in the houses at the Amarna Walled Village and Deir el-Medina were cylindrical, shaped somewhat like a large beehive, and constructed of an inner pottery liner covered with clay as insulation (Woolley 1922; Bruyère 1939: 72-73; Kemp 1987: 40). They resemble modern tannour or tandir ovens from the Middle East and India, and from fragmentary artistic evidence (Cooney 1965: 73; Kemp et al. 1994; Samuel 2000), it seems they were used in a similar way: a fire burned in the oven for approximately half an hour, then the flames were allowed to die down, and loaves were stuck to the inside of the oven, where they baked until they fell or were taken off (Henein 1988: 158-59; Samuel 1994: 277; 2000).

In order to analyse the significance of grain grinding for the creation of identity and power (or lack thereof) of those performing it, we need to know who was doing this work. No archaeological material provides explicit evidence of grain grinding being associated with a unique group, such as grinding stones being buried with a certain gender, age group, or socioeconomic class. As will be discussed below, Egyptian texts and artistic evidence point to women as the sole group performing grain grinding. This situation parallels nearly every other society in which grinding cereal was a crucial daily food-producing step. A multitude of ethnographic studies of modern societies also suggest that adolescent girls, as well as women, also performed this work (see for example, Asher 1986: 142; Brumfiel 1991; RodríguezAlegría 2012). As a means of limiting the discussion, this paper will focus on women as the grain grinders in the non-elite household.

Egyptian women ground grain using an oblong stone called a saddle quern and a smaller handstone. They placed a small amount of clean grain on the lower stone, and crushed it back and forth using the upper handstone. During the Old Kingdom and First Intermediate Period (c. 2600-2000 BCE), artistic depictions only show women grinding with the quern on the floor, working from a kneeling position (Breasted 1948: 16-30; Hudáková 2013), as in Figure 1. From the Middle Kingdom (c. 2000-1600 BCE) on, emplacements of mudbrick or wood begin to appear, which raise the quern off the floor, and set it at an angle sloping away from the operator (Winlock 1955: 28; Hudáková 2013), shown in Figure 2. Not every house at sites from the Middle Kingdom or later preserve quern emplacements. At Deir el-Medina, only eight out of 68 houses were equipped with these structures, often located in a rear room (Bruyère 1939: pl. XXIX). Quern emplacements were much more common in the Amarna Walled Village, where 33 out of 37 houses examined had them, usually in the front room (Samuel 1999). An emplacement made grinding much easier: less stress was placed on the lower back, knees, and toes, in particular, also making the milling process much faster. On the other hand, emplacements limited the mobility of those engaged in milling. While a saddle quern could be taken wherever the operator could carry it, if she used a quern emplacement, 
she was limited to one fixed location. The presence or lack of a quern emplacement may be an indication of the individual preferences of the inhabitants of each house.

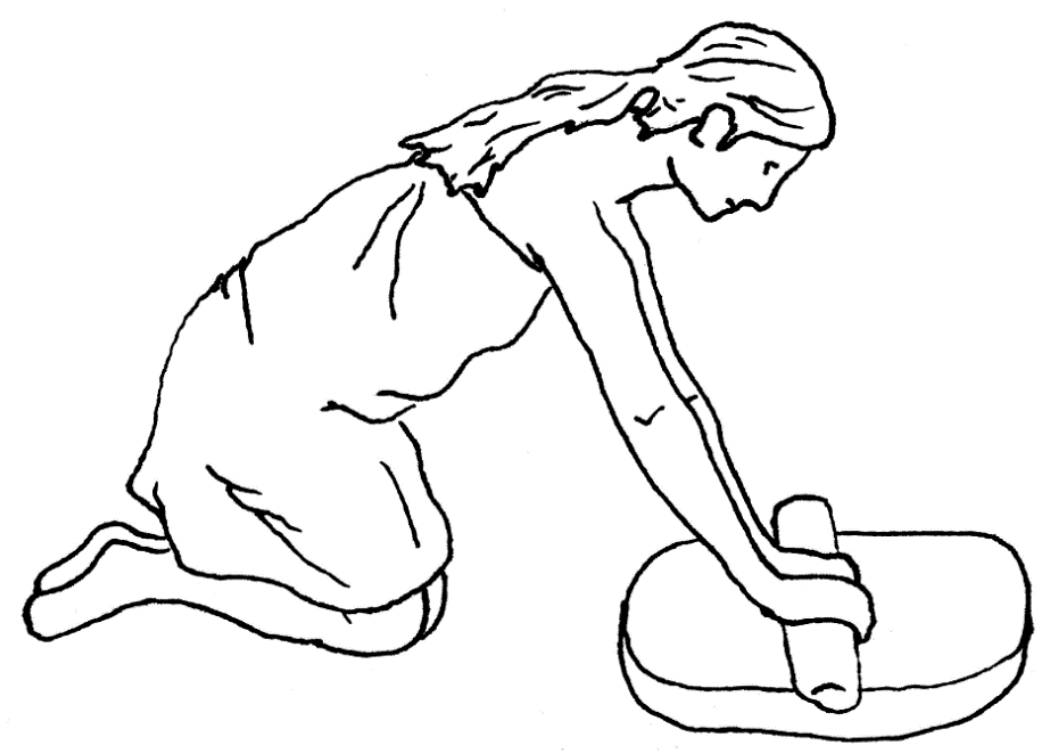

Figure 1: Woman grinding with quern on the floor. Drawing courtesy of J. Sylvia.

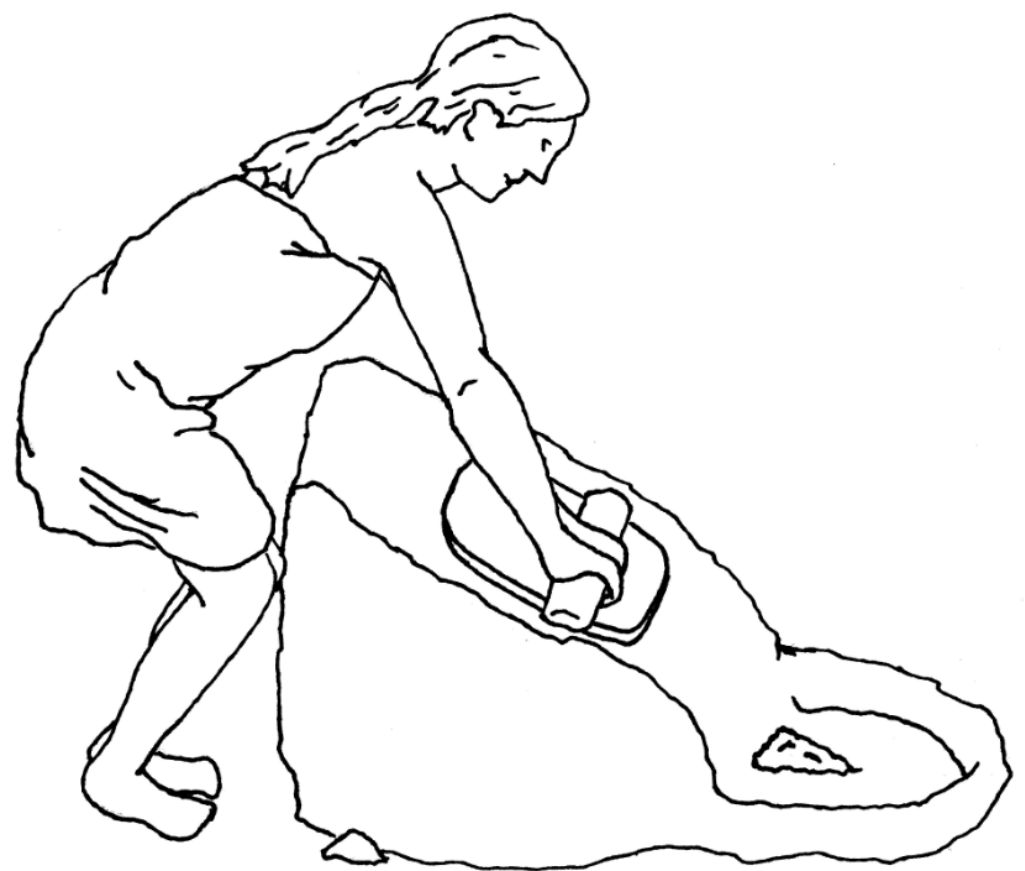

Figure 2: Woman grinding using a quern emplacement. Drawing courtesy of J. Sylvia.

Wildly varying estimates exist for how long an individual spent grinding enough emmer for their household, though these are sometimes not backed up by specific evidence. Through experiment, Samuel provides estimates of approximately two hours to grind $1.2 \mathrm{~kg}$ of emmer grain, and three hours to grind $2 \mathrm{~kg}$ (1994: 160; 2010: 464), though she notes an experienced miller would likely take less time. Another figure for ancient Egyptian grain grinding is seven to eight hours of grinding for one day's worth of flour (Adrario 2002: 21). In other cultures in which cereal grinding was crucial to the food supply, noted times include three hours for a family's daily meals in ancient Israel (Meyers 2002), 900 grams of wheat ground every 
fifteen or twenty minutes in Greece (Amouretti 1986: 138), and one hour, ranging up to four to eight hours, to grind enough soaked corn for a family for one day in Mexico (Brumfiel 1991; Rodríguez-Alegría 2012). Though these estimates vary wildly from author to author and culture to culture, in general it may be said that grinding cereal took up a significant portion of the day. How did such a time-and labour-intensive activity reflect on those who performed it? What impact did grain grinding have on household organization, and individual identity?

\section{Discussion and Conclusions:}

As mentioned above, ethnographic parallels from the vast majority of cultures in which cereal grinding took place suggest that it was primarily the province of females. This is particularly indicated by the ancient Egyptian artistic record. In tomb paintings, which depicted primarily elite, industrial-scale bread-making, both men and women could be shown participating in all other steps of the emmer processing sequence. However, only women were ever shown grinding grain. This was the only step for which this differentiation existed. Such distinction is also true for small-scale statuettes depicting figures engaged in emmer processing, dating primarily to the Old Kingdom (Breasted 1948: 17-25), as well as tomb models from the Middle Kingdom (Winlock 1955: 28). Very few exceptions to this rule exist: less than ten statuettes from the New Kingdom show males grinding (Gardiner 1906; Breasted 1948: 22-24; Dodson 1990). However, these are clearly elite men, shown wearing expensive clothing and wigs, often with inscriptions describing that they are grinding "for their god," and magic spells placing them more in the context of shawabti statuettes than servant statuettes (Roth 2002). These were men who clearly were not shown grinding grain for a household on a daily basis, but rather in a specific ritual context. As a result, it is unlikely that the New Kingdom elite male grain grinding statuettes have the same meaning as earlier female depictions, and need not be considered here.

A variety of texts also attest to the female nature of grinding. Maxim 1 of the Middle Kingdom Instruction of Ptahhotep reads: "Perfect speech is concealed, more than emerald; (yet) it is found with the maids at millstones" (Parkinson 1991: 67). Similarly, the late Middle Kingdom Admonitions of Ipuwer describe a distressing, topsy-turvy situation in which the female elite are treated like servants: “ $O$, yet dependents are put to quernstones; those who used to wear fine linen are beaten wrongly, (and) those who used not to see the day have come forth unhindered... rich ladies suffer (just) like maidservants; [music]ians are at the loom (?) within the weaving rooms, their weavers' songs being dirges; tellers [of words(?) are at] quernstones" (Enmarch 2008: 225-226). A passage from the tomb of Panehsy, dated to the reign of Ramses II (Onstine 2011), mentions grinding stones (bnw.t) as well as female millers ( $n \underline{d} w . t$ - note the feminine t-endings of both terms) (see el-Sawi \& Gomaa 1993: 48 for text). Even one term for "maidservants," $n \underline{d} . t y$, comes from the same root which incorporates the verb "to grind" ( $n \underline{d})$ and the noun "miller" ( $n \underline{d} w)$ (Erman \& Grapow 1928: 369-70). These references, among others, indicate that it is typically women who perform grain grinding.

Ancient Egyptian textual and artistic evidence suggesting that grinding was solely a female occupation are corroborated by a variety of comparisons with other ancient and modern societies. Old Babylonian contracts describe workers hired to process grain: while men do participate in coarse, presumably preliminary, grain grinding, it is women who are the fine grinders (Postgate 1984). These processes might correspond to depictions of ancient Egyptian industrial bakeries where males pound grain, while women grind it on querns (see for example, Davies 1920: pl. XI; Winlock 1955: 27-29). The Bible also records a variety of instances of grain grinding or grindstones, all of which concern females (Meyers 2002). Exodus 11:5 describes the "(Egyptian) female slave who is behind the handmill," Isaiah 47:2 
addresses "virgin daughter Babylon" by instructing her to "take the millstones and grind meal," and Job 31:10 records that if a man is unfaithful, "then let my wife grind for another." These passages unequivocally equate grinding with women. Women were associated with grinding even in times of war, using grinding tools as weapons: Judges 9: 53 and 2 Samuel 11:21 record that "a certain woman threw an upper millstone on Abimelech's head.” Only two instances involve males grinding grain, either as prisoners in Judges 16.21 or as indicators of a backward situation in Lamentations 5.13, but these may be taken as exceptions that prove the rule: both of these examples show men grinding grain as an indication that something is wrong or the man is a criminal. In general, these texts imply that grinding grain is a defining characteristic of being female, and of filling the role in the household economy normally performed by women.

Osteological markers on ancient skeletons corroborate the female association of grinding. Anne Austin, studying skeletons at Deir el-Medina, the comparable site to Amarna, records two female skeletons which have severe knee joint damage, the most extensive joint damage of either gender in the Deir el-Medina assemblage (Austin 2014). She suggests that this might be as a result of grinding grain over long periods of time (Austin 2014: 204). This matches findings from a study of early Neolithic skeletons from Abu Hureyra in northern Syria. The author noted a set of osteological markers she associated with grain grinding while kneeling. Among these were compressed last dorsal vertebrae, arthritic big toes, and knee joint degeneration, which indicate sustained strain on the lower back, toes, and knees, as well as symmetrical muscle markers on the humerus (deltoid) and the radius (biceps), which show symmetrical development of the shoulder and arm muscles consistent with pushing a handstone across a quern (Molleson 1994). Similarly, a study of pre-Hispanic Maya in Mexico showed that females developed bilaterally symmetrical markers on the arms, which the authors attribute to food processing, particularly grinding, compared to males, in whom one dominant arm developed more than the other (Wanner et al. 2007).

Several modern examples also identify grain grinding as a specifically female activity. Recent ethnographic work in Mexico describes the experiences of women grinding nixtamel (corn soaked in water and lime) for their families. Only females did this work, often as young girls under the instruction of their mothers (Rodríguez-Alegría 2012). A similar situation can be identified in immediately post-Hispanic Mexico, where an instruction text, the Codex Mendoza, shows mothers and daughters performing specifically female work, of which one activity is cereal grinding (Brumfiel 1991). Women and girls were also observed grinding in modern Saharan nomadic tribes: "I often watched Hawa as she placed a few grains at a time on the stoop of the base-stone and let them trickle down as she ground them, sweeping the flour into a bowl every few minutes. After an hour or so her little daughter, aged about nine, would take over and begin grinding furiously. It might take several hours to produce enough flour for one meal.” (Asher 1986: 142). Similarly to what is implied by Job 31:10, Livingstone's account of his expedition to the Zambesi records that grinding grain was associated with being a wife, part of the female's economic domain in the house (Livingstone \& Livingstone 1866: 568-570).

The evidence discussed above also suggests that grinding grain was a low-prestige activity. Ancient Egyptian women depicted grinding are generally shown wearing plain clothes, often with their hair covered, rather than dressed fashionably in elaborate wigs and fine linens (Breasted 1948: 16-30; Hudáková 2013). They are also sometimes shown as old or haggard, contrasting the permanently youthful appearance of elite female figures (Sweeney 2004). The Admonitions of Ipuwer describes a reversed world where the elite suffer and servants are elevated; this is emphasized by the elite being forced to perform tasks which are evidently the domain of the lowest classes or servants, among which grinding is mentioned several times. In the Instruction of Ptahhotep the author tells the reader that wisdom may be 
found anywhere, by noting that "good speech" can be found even among the lowly maidservants at their mill stones. That this is an unexpected location for "good speech" implies that those who perform grain grinding would not normally be a source for wisdom or prestige. Even the root of "to grind," with its associated noun translated as "maidservants," implies that the ancient Egyptians strongly associated the act of grinding with females of servant status. In Deir el-Medina, government ration lists record that each workman received a set number of "work-days" from state-supplied female servants or slaves (Janssen 1997: 23; Toivari-Viitala 2001: 97). It has been hypothesized that the primary work of these women was grinding grain for the workmen's families (Černý 1973: 177; Hofmann 2006). If it is the case that someone of lower status was paid to perform the grain grinding, this would emphasize the distasteful nature of grinding. These women may correspond to the abovementioned female skeletons with extremely damaged knee joints in the Deir el-Medina osteological record. Parallels in contemporary societies also reinforce this point. Texts indicate that grinding was performed by prisoners in a few instances in the Bible. Modern informants in Mexico reported that grinding nixtamel was an upsetting, undesirable experience, implying that it would be left to those with low status (Rodríguez-Alegría 2012).

Rodríguez-Alegría also recorded that this experience could be made better by grinding in a group, as was the case when Mexican women prepared large amounts of food for feasts on special occasions. The desire to perform grain grinding as a group may also be indicated in PPNA and Early-Middle PPNB sites in the Levant, where milling and cooking installations can be found near or at house entrances, in the community space (Wright 2000). Samuel hypothesizes that some household pairs may have shared pounding and milling resources (1999), which may have resulted in small groups working together. The frequent location of quern emplacements in the front room of Amarna houses (near the street) may also have facilitated women working with their neighbours. In Deir el-Medina, the lack of grinding emplacements in the majority of Deir el-Medina houses may also reflects a situation where some women left the privacy of their homes to grind grain as a group, if a servant woman was not performing the grinding that day.

Though grinding was low-prestige, it was also ubiquitous and necessary. As noted above, texts from Deir el-Medina suggest that female servants may have been available to perform some of the grinding. Unfortunately, the paucity of written material from the Amarna Walled Village means there is no indication whether or not such services were available there. However, the higher frequency of preserved quern emplacements at the Amarna Walled Village may indicate that it was more common for women of individual households to grind grain themselves. This work was crucial for the survival of the household: cereals were a large part of the total calories Egyptians consumed, bread was the favoured way of consuming cereals, and grinding was necessary to make bread. Grinding grain is thus an excellent example of the type of labour called "maintenance activities" which regulate and stabilize social life, and may involve specialized knowledge and the ability to sustain interpersonal relationships (González-Marcén et al. 2008).

This activity also was a labour that would sometimes have been shared between mother and daughter, as several ethnographic accounts suggest (Asher 1986: 142; Brumfiel 1991; Rodríguez-Alegría 2012). It was thus a learning experience, of one generation teaching the next, both how to grind as well as how to learn. Grinding was also a socializing and social activity - women socialized young girls through teaching, and women and girls grinding together shared news and forged connections that drew a neighbourhood or community together.

Though the concept of maintenance activities stresses the importance of these labours within the household, grinding is also important for work beyond the house. As Brumfiel notes, dry, portable food could be carried by those working far from the home (Brumfiel 
1991). Indeed, the Middle Kingdom story of the Eloquent Peasant provides an excellent Egyptian example of this: the Peasant, leaving home for several days, enables his travels by instructing his wife to bake enough bread to last through his whole trip (Parkinson 2012: 2729). As attested by the aforementioned New Kingdom male statuettes, grinding also facilitated ritual interaction with the gods and the ancestors, who required offerings primarily of bread and beer. A reciprocal relationship existed between the living and supernatural beings such as dead ancestors or deities, where the living provided gods and the dead with food offerings, and in return these supernatural beings maintained the world and its natural rhythms, and intervened positively in the lives of the living individuals. On a large scale, it might thus be said that grinding grain to make bread (along with beer and other offerings) "made the world go round."

What emerges from the above discussion is a tension concerning the nature of grain grinding: it was an activity that was incredibly important, but lacking in prestige in New Kingdom Egyptian society. As a crucial maintenance activity, grinding grain for bread facilitated the reproduction of the household, and the socialization of children, and was allocated a large amount of resources in terms of time, space, and labour. On the other hand, the evidence cited above suggests that this activity was viewed as distasteful, low-prestige work, possibly due in part to its labour-intensive, repetitive nature. This parallels similar tensions in many modern societies, where low prestige is accorded to occupations such as waste collector or janitor, despite their extreme importance for the proper functioning of the community. The low prestige of grinding in ancient Egypt may have meant that other parts of the bread making sequence carried higher prestige, indicating that someone with more power in the household would delegate work she didn't want to do, and perform the activities for which she would receive more prestige or social credit. A woman or girl's role in the grain preparation sequence would thus be an indicator of her status and identity within the household. If we can hypothesize what household members might have been performing the different steps of bread-making, then we can begin to understand how labour in ancient Egyptian households was organized, and how household hierarchies were constructed.

Grinding may also have not had solely negative connotations. Grinding in groups provided the opportunity for socializing and networking crucial to the function of the community. Modern ethnographic parallels suggest that grain grinders also took great pride in the bread they produced (Rodríguez-Alegría 2012), possibly earning status through the skill with which they performed. As a means of enabling work far outside the house by creating a dry, portable food, those who ground grain thus had a significant impact, and an identity, outside the house through the bread they produced.

Studying those who performed grain grinding and the wider bread producing sequence in non-elite New Kingdom households is thus a fruitful means of investigating ancient Egyptian women. Through reconstructing this work through archaeology, text and art, and comparative evidence, we can learn about labour organization, household hierarchies, and social interactions, as well as discovering hints of the self-identity of these individuals.

\section{Acknowledgements}

I would like to thank the organizing committee of the first meeting of the Association of Ground Stone Tools Research for a wonderfully informative conference. I would also like to thank the conference participants for their thoughtful questions and critiques. Thanks are also due to the William K. and Marilyn M. Simpson Endowment for Egyptology for their very generous support. 


\section{References}

Adrario, C. 2002, "Ta" - Getreide und Brot im alten Ägypten. Deutsches Brotmuseum, Ulm, 67 p. (in German) (““Ta' - Grain and bread in ancient Egypt”)

Amouretti, M. C. 1986, Le Pain et l'Huile dans la Grèce Antique: de l'Araire au Moulin. Belles Lettres, Paris, 322 p. (in French) ("Bread and oil in ancient Greece: from the plow to the mill”)

Asher, M. 1986, A Desert Dies. Viking, Harmondsworth, Middlesex, 330 p.

Austin, A. 2014, Contending with Illness in Ancient Egypt: A Textual and Osteological Study of Health Care at Deir el-Medina. PhD Dissertation, University of California, Los Angeles, $301 \mathrm{p}$.

Breasted, J. H. 1948, Egyptian Servant Statues. Pantheon Books, New York, 113 p.

Brumfiel, E. 1991, Weaving and cooking: Women’s production in Aztec Mexico. In: Engendering Archaeology: Women and Prehistory, (Gero, J. M., \& Conkey, M. W., Eds.), Basil Blackwell, Ltd., Oxford: p. 224-251.

Bruyère, B. 1939, Rapport sur les Fouilles de Deir el Médineh (1934-1935). Imprimerie de l'Institut français d'archéologie orientale, Cairo, 384 p. (in French) ("Report on the excavations of Deir el-Medina (1934-1935)")

Černý, J. 1973, A Community of Workmen at Thebes in the Ramesside Period. Institut Français d'Archéologie Orientale, Cairo, 383 p.

Cooney, J. 1965, Amarna Reliefs from Hermopolis in American Collections. The Brooklyn Museum, Brooklyn, 110 p.

Davies, N. de G. 1920, The Tomb of Antefoker, Vizier of Sesostris I, and of His Wife, Senet (No. 60). George Allen \& Unwin, Ltd., London, 40 p.

Dodson, A. 1990, Crown prince Djhutmose and the royal sons of the eighteenth dynasty. The Journal of Egyptian Archaeology, 76: 87-96. doi:10.2307/3822009

Enmarch, R. 2008, A World Upturned: Commentary on and Analysis of The Dialogue of Ipuwer and the Lord of All. Oxford University Press, Oxford, 294 p.

Erman, A., \& Grapow, H. 1928, Wörterbuch der Ägyptischen Sprache. Zweiter Band. J.C. Hinrichs, Leipzig, 506 p. (in German) ("Dictionary of Egyptian Language. Second Volume”)

Foxhall, L., \& Forbes, H. A. 1982, Sitometria: The role of grain as a staple food in Classical Antiquity. Chiron, 12: 41-90.

Gardiner, A. H. 1906, A statuette of the high priest of Memphis, Ptahmose. Zeitschrift für Ägyptische Sprache und Altertumskunde, 43: 55-59. doi:10.1524/zaes.1908.4344.jg.55

González-Marcén, P., Montón-Subías, S., \& Picanzo, M. 2008, Towards an archaeology of maintenance activities. In: Engendering Social Dynamics: The Archaeology of Maintenance Activities, (Montón-Subías, S., \& Sánchez-Romero, M., Eds.), Archaeopress, Oxford: p. 3-8.

Henein, N. H. 1988, Mārī Girgis: Village de Haute-Égypte. Institute Français d’Archéologie Orientale du Caire, Cairo, 443 p. (in French) ("Mārī Girgis: Upper Egyptian Village") 
Hofmann, T. 2006, Arbeitseinsätze und Löhne der sogenannten Sklavinnen von Deir elMedine. In: Living and Writing in Deir el-Medine: Socio-Historical Embodiment of Deir el-Medine Texts, (Dorn, A., \& Hoffman, T., Eds.), Schwabe AG, Verlag, Basel: p. 113-118. (in German) ("Work assignments and wages of the so-called slaves of Deir elMedina”)

Hudáková, L. 2013, Innovative power of Middle Kingdom tomb decoration as reflected in the scenes of grain processing, bread-making, and brewing. In: Florilegium Aegyptiacum: eine wissenschaftliche Blütenlese von Schülern und Freunden für Helmut Satzinger zum 75. Geburtstag am 21. Jänner 2013, (Budka, J., Gundacker, R., Pieke, G., \& Satzinger, H., Eds.), Seminar für Ägyptologie und Koptologie der Georg-August-Universität, Göttingen, p. 159-188.

Janssen, J. J. 1997, Village Varia: Ten Studies on the History and Administration of Deir elMedina. Nederlands Instituut voor het Nabije Oosten, Leiden, 192 p.

Kemp, B. 1984, Amarna Reports I. The Egypt Exploration Society, 3 Doughty Mews, London, $211 \mathrm{p}$.

Kemp, B. 1986, Amarna Reports III. The Egypt Exploration Society, 3 Doughty Mews, London, 212 p.

Kemp, B. 1987, Amarna Reports IV. The Egypt Exploration Society, 3 Doughty Mews, London, $167 \mathrm{p}$.

Kemp, B., Samuel, D., \& Luff, R. 1994, Food for an Ancient Egyptian city: Tell el-Amarna. In: Whither Environmental Archaeology? (Luff, R., \& Rowley-Conwy, P., Eds.), Oxbow Books, Oxford: p. 133-170.

Livingstone, D., \& Livingstone, C. 1866, Narrative of an Expedition to the Zambesi and its Tributaries: and of the Discovery of the Lakes Shirwa and Nyassa, 1858-1864. Harper \& Brothers, New York, 638 p.

Meyers, C. 2002, Having their space and eating there too: Bread production and female power in ancient Israelite households. Nashim: A Journal of Jewish Women's Studies \& Gender Issues, 5: 14-44. doi:10.2307/40326551

Molleson, T. 1994, The eloquent bones of Abu Hureyra. Scientific American, 271(2): 70-75. doi:10.1038/scientificamerican0894-70

Onstine, S. 2011, University of Memphis Mission to Theban Tomb 16: The life of Panehsy, chanter and priest. Journal of the American Research Center in Egypt, 47: 231-236.

Parkinson, R. B. 1991, Voices from Ancient Egypt. An Anthology of Middle Kingdom Writings, British Museum Press, London, 160 p.

Parkinson, R. B. 2012, The Tale of the Eloquent Peasant: A Reader's Commentary, Widmaier Verlag, Hamburg, 384 p.

Peet, T. E. 1921, Excavations at Tell el-Amarna: A preliminary report. The Journal of Egyptian Archaeology, 7(3/4): 169-185. doi:10.2307/3853563

Peet, T. E., \& Woolley, L. 1923, The City of Akhenaten. Part I. Egypt Exploration Society, London, $176 \mathrm{p}$.

Postgate, J. N. 1984, Processing of cereals in the cuneiform record. Bulletin on Sumerian Agriculture, 1: 103-113. 
Rodríguez-Alegría, E. 2012, From grinding corn to dishing out money: A long-term history of cooking in Xaltocan, Mexico. In: The Menial Art of Cooking: Archaeological Studies of Cooking and Food Preparation, (Graff, S. R., \& Rodríguez-Alegría, E., Eds.), University Press of Colorado, Boulder: p. 99-117.

Roth, A. M. 2002, The meaning of menial labor: 'servant statues' in Old Kingdom Serdabs. Journal of the American Research Center in Egypt, 39: 103-121. doi:10.2307/40001151

Samuel, D. 1994, An Archaeological Study of Baking and Bread in New Kingdom Egypt. PhD Dissertation at Darwin College, University of Cambridge, Cambridge, 343 p.

Samuel, D. 1999, Bread making and social interactions at the Amarna workmen's village, Egypt. World Archaeology, 31(1): 121-144. doi:10.2307/125099

Samuel, D. 2000, Brewing and baking. In: Ancient Egyptian Materials and Technology (Nicholson, P. T., \& Shaw, I., Eds.), Cambridge University Press, Cambridge: p. 537-576.

Samuel, D. 2010, Experimental grinding and ancient Egyptian flour production. In: Beyond the Horizon: Studies in Egyptian Art, Archaeology and History in Honour of Barry J. Kemp, (Ikram, S., \& Dodson, A., Eds.), American University in Cairo Press, Cairo: p. 456-477.

el-Sawi, A., \& Gomaa, F. 1993, Das Grab des Panehsi, Gottesvaters von Heliopolis in Matariya. Harrassowitz Verlag, Wiesdbaden, 134 p. (in German) ("The Tomb of Panehsi, God's Father of Heliopolis in Matariya”)

Schiaparelli, E. 1923, Relazioni sui Lavori della Missione Archeologica Italiana in Egitto (Anni 1903 - 1920) I: Esplorazione della "Valle delle Regine" Nella Necropolis di Tebe. R. Museo di Antichità, Turin, 206 p. (in Italian) ("Reports on the work of the Italian archaeological mission in Egypt (1903-1920) I: Exploration of the 'Valley of the Queens' in the necropolis of Thebes”)

Sweeney, D. 2004, Forever young? The representation of older and aging women in Ancient Egyptian art. Journal of the American Research Center in Egypt, 41: 67-84. doi:10.2307/20297188

Toivari-Viitala, J. 2001, Women at Deir el-Medina: a Study of the Status and Roles of the Female Inhabitants in the Workmen's Community during the Ramesside Period. Nederlands Instituut Voor Het Nabije Oosten, Leiden, 293 p.

Wanner, I. S., Sosa, T. S., Alt, K. W., \& Blos, V. T. 2007, Lifestyle, occupation, and whole bone morphology of the pre-Hispanic Maya coastal population from Xcambó, Yucatan, Mexico. International Journal of Osteoarchaeology, 17(3): 253-268. doi:10.1002/oa.873

Winlock, H. E. 1955, Models of Daily Life in Ancient Egypt. Harvard University Press, Cambridge, $106 \mathrm{p}$.

Woolley, C. L. 1922, Excavations at Tell el-Amarna. The Journal of Egyptian Archaeology, 8(1/2): 48-82. doi:10.2307/3853624

Wright, K. 2000, The social origins of cooking and dining in early villages of Western Asia. Proceedings of the Prehistoric Society, 66: 89-121. doi:10.1017/S0079497X0000178X 